\title{
Gender Affects Clinical Suspicion of Down Syndrome
}

\author{
Natalia V. Kovaleva \\ St. Petersburg State Pediatric Medical Academy under \\ the Federal Agency of Health Care and Social Development \\ Russian Federation
}

\section{Introduction}

It is known that the Down syndrome phenotype can result from a triplication of a small portion of chromosome 21. In the majority of cases diagnosed as Down syndrome (90\%), free trisomy for chromosome 21 is found; in some $6 \%$ of the cases translocations are observed, and about $3 \%$ are mosaics with normal cell line; other aberrations involving chromosome 21 are rare and found in less than 1\% [Mikkelsen, 1988]. In a huge literature on the epidemiology of Down syndrome, there are two features undoubtedly established, a strong association of free trisomy 21 frequency with advanced maternal age, and male prevalence among patients with Down syndrome due to regular trisomy 21.

Generally, the clinical diagnosis is straightforward and well-known to all medical workers [Mikkelsen, 1988]. However, misdiagnosis (false positive diagnosis) of Down syndrome was reported in numerous publications [Ahmed et al., 2005; Baccichetti et al., 1990; Ballesta et al., 1977; Engel et al., 1970; Fried et al., 1980; Hamerton et al., 1965; Melve et al., 2008; Szollar et al., 1983], being particularly high in neonates [Devlin \& Morrison, 2004; Hindley \& Medakkar, 2002]. Factors which alter suspicion of trisomy 21 are known to be early delivery and prematurity [Mikkelsen, 1988].

Previous studies reported a significant female prevalence among Down syndrome patients with clinical diagnosis only which suggested that gender also may alter a suspicion of Down syndrome in infants [Kovaleva et al., 1999; Kovaleva, 2002]. Therefore, the main objectives of this study were to evaluate a rate of false positive diagnosis of Down syndrome in a large well-defined geographically population and to determine male-to-female ratio (sex ratio, $\mathrm{SR}$ ) among patients with false-positive diagnosis.

\section{Materials and methods}

St. Petersburg is a large city with a population of about 5 million, and an average of 50000 births a year. Almost all births take place in a hospital. There is one major clinical genetic unit in the city which provides the service to the target population, the St. Petersburg Centre for Medical Genetics. The overwhelming majority of live born babies suspected to have genetic disease have been examined by clinical geneticists from the Centre within the first several days after birth and prior to discharge from a hospital. Medical personnel at children hospitals and special institutions for handicapped children may also call for a clinical 
geneticist for suspected genetic condition. It is mandated that few cases born in private hospitals and tested cytogenetically elsewhere, must be reported to the Centre. Older patients or their parents can arrange an appointment to the Centre themselves after being referred to by medical specialists. Only certified clinical geneticists at St. Petersburg Centre for Medical Genetics can request karyotyping to confirm or refute a suspected chromosomal abnormality.

In St. Petersburg, due to global social transition, the birth rate fell dramatically from about 73 thousand in 1987 to 29 thousand in 1999 which caused a decline in the number of live born patients with Down syndrome over time. Since 2000, the birth rate begun to increase steadily, reaching more than 50 thousand in 2009. However, at the same time, since 2000, the impact of prenatal diagnosis on the prevalence of Down syndrome prevalence has been expanding rapidly, affecting the number of live born babies with Down syndrome.

The completeness of cytogenetic confirmation of trisomy 21 varied significantly, increasing from $21 \%$ in 1970 to almost $100 \%$ currently. Therefore, for the sake of sufficient sample size, the author has chosen for the analysis the period of 1986-2009, when data completeness had begun improving from $82 \%$ in 1986 to about $100 \%$ in 1999 and upward.

All cases of Down syndrome delivered during the period January 1, 1986 to December 31, 2009 were abstracted from a population-based registry, the St. Petersburg Down Syndrome Register, founded and run by the author. The Register has been collecting data on all Down syndrome patients residing in St. Petersburg, whether diagnosed antenatally or live born since 1970. The method for data collection has been described elsewhere [Kovaleva et al., 2001].

Data on patients suspected to have Down syndrome but with a normal karyotype were retrieved from logbooks of the cytogenetic laboratory at the St. Petersburg Centre for Medical Genetics and from logbooks of the cytogenetic laboratory at the Leningrad Oblast Children Hospital which provides service to the regions surrounding St. Petersburg. The degree of certainty of the Down syndrome diagnosis was determined by presence of question mark(s) in the records of indication for karyotyping in the logbooks. When the diagnosis at clinical examination seemed obvious, the question mark was absent. In doubtful cases, sometimes up to three question marks presented in the record. In some cases, suspected mosaicism was an indication. The data obtained were analyzed using standard statistics including binomial test and Chi-square test with Yates correction.

\section{Results}

Over a period of twenty-four years (from 1.01.1986 to 31.12.2009), 1257 children had been referred to cytogenetic investigation for either confirmation or exclusion of trisomy 21 . The Down syndrome diagnosis was confirmed in 1129 (89.8\%) of them and 120 (9.5\%) children had a normal karyotype. The remaining eight children with another chromosomal abnormality were excluded from the analysis (Table 1). 1119 cases of trisomy 21 were diagnosed in the St. Petersburg Centre for Medical Genetics and ten cases were diagnosed elsewhere. The sex ratio among children with confirmed DS diagnosis was skewed, with a surplus of males (612 males/517 females, $\mathrm{SR}=1.18)$. In contrast, among children with a normal karyotype, there was a strong female prevalence ( 25 males/ 95 females, $S R=0.26$ ), the difference is highly significant, $\mathrm{p}<<0.0001$.

Neonates constituted $94 \%$ of patients with confirmed Down syndrome while a proportion of neonates among those with false positive diagnosis was appreciably smaller $(65 \%)$. 
Therefore a proportion of false positive cases among neonates was $6.8 \%$ compared to $35 \%$ in patients aged one month and older (Table 1). The annual rate of false positives among neonates varied from $0 \%$ in 1990, 1995, and in 2000 to $21 \%$ in 2008 (Figure 1). There was an apparent trend with an increase in false positives in relation to a reduction in the number of cases tested. This variation did not depend on the clinical experience of the referring doctors. For example, 8 of 9 false positive cases in 2008 were referred to cytogenetic testing by clinical geneticists whose experience had exceeded 15 years, and the remaining one case was suspected to have Down syndrome by a clinical geneticist with 7 years of experience.

\begin{tabular}{lcccc}
\hline & True Down & \multicolumn{2}{c}{ False positive diagnosis } & \\
\cline { 3 - 4 } Age of patients & $\begin{array}{c}\text { syndrome } \\
\text { (trisomy 21) }\end{array}$ & $\begin{array}{c}\text { Normal } \\
\text { karyotype }\end{array}$ & $\begin{array}{c}\text { Other } \\
\text { chromosomal } \\
\text { abnormality }\end{array}$ & Total \\
\hline Neonates & 1063 & 77 & 6 a & 1146 \\
Patients under 1 yo & 59 & 20 & $2 \mathrm{~b}$ & 81 \\
$\begin{array}{l}\text { Patients aged 1 yo } \\
\text { and older }\end{array}$ & 7 & 23 & 8 & 1257 \\
\hline Total & 1129 & 120 & 8 \\
\hline
\end{tabular}

a 46,XY,18p-; 46,XX,t(11;22); 46,X,t(X;16)(p11;q13); 46,XX,r(18); 46,XX, r(18); 47,XXX

b 46,XY, add(10)(q26); 46,XX,inv(22)(p13;q12)

Table 1. Proportion of false positive diagnosis according to the patients' age at cytogenetic examination

Among false positive neonates, there was a very strong female prevalence, with 11 males/ 66 females, $\mathrm{SR}=0.17$. Notable female predominance was also found in both patients aged under 1 year old $(7$ males $/ 13$ females, $S R=0.54)$ and in older patients $(7$ males $/ 16$ females, $\mathrm{SR}=0.44)$.

Further analysis was performed regardless of the date and place of birth of the patients. Overall, a normal karyotype was diagnosed in 103 neonates $(17$ males $/ 86$ females, $S R=0.20$, different from population value of 1.06, $\mathrm{p}<0.0001)$, in 68 children of the age group up to 1 year old $(24 \mathrm{M} / 44$ females, $S R=0.55, \mathrm{p}=0.0052)$, and in 64 children aged 1 year and older $(29 \mathrm{M} / 35$ females, $\mathrm{SR}=0.83, \mathrm{p}>0.05)$.

Data on the level of certainty in false positives cases is presented in Table 2 . The diagnosis at clinical examination seemed obvious in $22 \%$ of neonates and in only $6 \%$ of children 1 year and older. In two cases, since features of Down syndrome were obvious, chromosome testing was requested twice. The proportion of suggested mosaicism was increased with the patients' age, from $3 \%$ in neonates to about $10 \%$ in the oldest group of patients. Request for excluding Down syndrome was noted in two cases only. Unquestionable Down syndrome diagnosis was stated in $20 \%$ and mosaicism was suspected in about $9 \%$ of males, while in females these figures were $14 \%$ and $4 \%$ correspondingly (Table 3 ). 


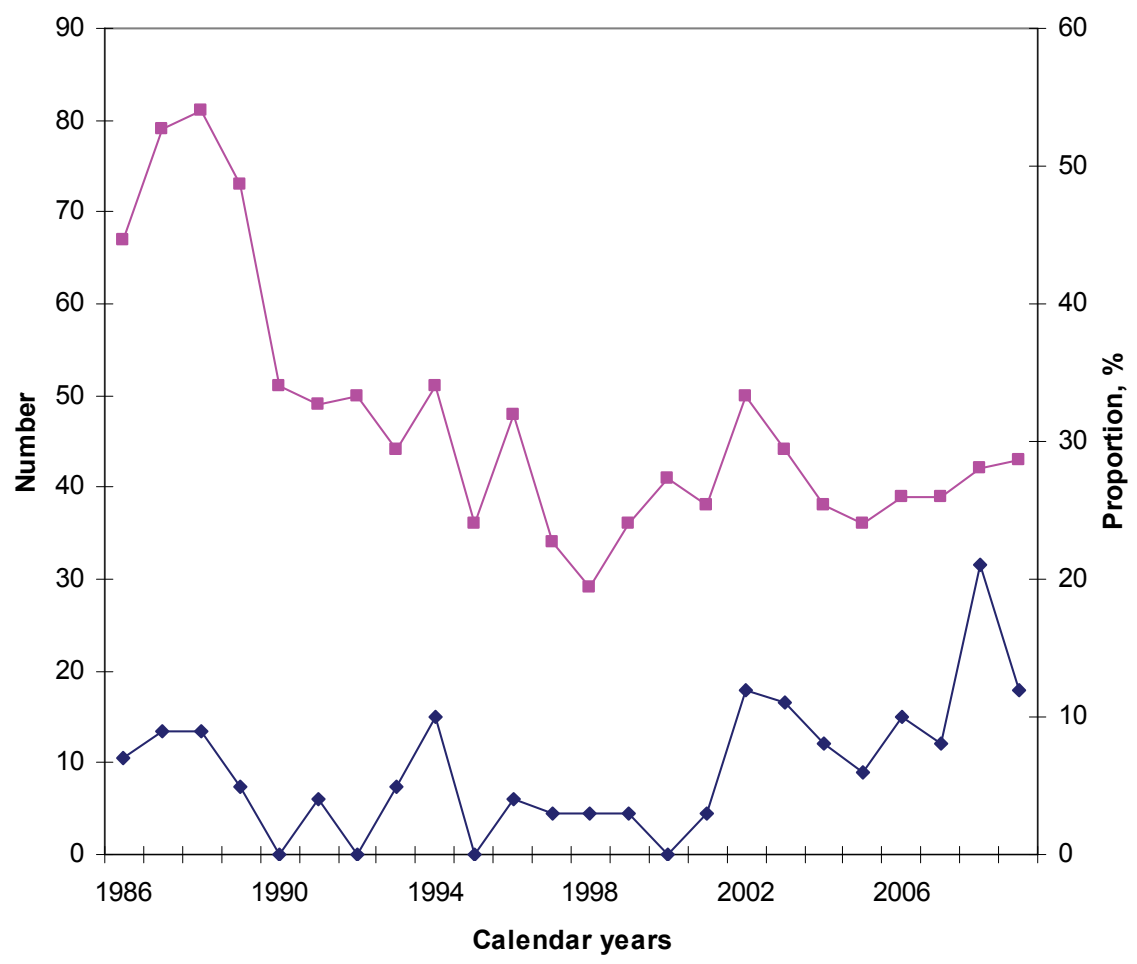

Fig. 1. Total number of cytogenetically tested cases (red line) and proportion of cases with false positive diagnosis (blue line).

\begin{tabular}{lcccc}
\hline \multirow{2}{*}{ Expression of certainty } & \multicolumn{4}{c}{ Patients with false positive diagnosis of Down syndrome } \\
\cline { 2 - 5 } & Neonates & Under 1 yo & 1 yo and older & Total \\
\hline Down syndrome & $22(22 \%)$ & $11(16 \%)$ & $4(6 \%)$ & 37 \\
Mosaicism? & $3(3 \%)$ & $3(4.5 \%)$ & $6(9.5 \%)$ & 12 \\
Down syndrome? & $60(58 \%)$ & $51(75 \%)$ & $53(83 \%)$ & 164 \\
Down syndrome?? & $14(14 \%)$ & $2(3 \%)$ & $1(1.5 \%)$ & 17 \\
Down syndrome??? & $2(2 \%)$ & $1(1.5 \%)$ & & 3 \\
Request for excluding & $2(2 \%)$ & & & 2 \\
Down syndrome & 103 & 68 & 64 & 235 \\
\hline Total &
\end{tabular}

Table 2. Degree of certainty in requesting for cytogenetic testing according to the age of the patients 


\begin{tabular}{|c|c|c|c|c|c|}
\hline \multirow{2}{*}{\multicolumn{3}{|c|}{ Expression of certainty }} & \multicolumn{3}{|c|}{$\begin{array}{l}\text { Patients with false positive diagnosis of Down } \\
\text { syndrome }\end{array}$} \\
\hline & & & Males & Females & Total \\
\hline \multicolumn{3}{|c|}{ Down syndrome } & $14(20 \%)$ & $23(14 \%)$ & 37 \\
\hline \multicolumn{3}{|l|}{ Mosaicism? } & $6(8.5 \%)$ & $6(4 \%)$ & 12 \\
\hline \multicolumn{3}{|c|}{ Down syndrome? } & $47(67 \%)$ & $117(71 \%)$ & 164 \\
\hline \multicolumn{3}{|c|}{ Down syndrome?? } & $2(3 \%)$ & $15(4 \%)$ & 17 \\
\hline \multicolumn{3}{|c|}{ Down syndrome??? } & $1(1.5 \%)$ & $2(1 \%)$ & 3 \\
\hline \multicolumn{3}{|c|}{$\begin{array}{l}\text { Request for excluding Down } \\
\text { syndrome }\end{array}$} & 0 & $2(1 \%)$ & 2 \\
\hline \multicolumn{3}{|l|}{ Total } & 70 & 165 & 235 \\
\hline \multicolumn{6}{|c|}{$\begin{array}{l}\text { Table } 3 \text {. Degree of certainty in requesting for cytogenetic testing according to the gender of } \\
\text { patients with false positive diagnosis }\end{array}$} \\
\hline \multicolumn{6}{|c|}{$\begin{array}{l}\text { Data on distribution of both true Down syndrome patients and false positives by maternal } \\
\text { age is presented in Table } 4 \text {. The analysis of maternal age distribution in false positive } \\
\text { patients was complicated since maternal ages were available in only a small proportion of } \\
\text { the sample. There is some increase }(13 \%) \text { in the proportion of mothers aged } 35 \text { years old and } \\
\text { older compared to general population }(6 \% \text { to } 9 \%) \text {, due to a higher proportion }(23.5 \%) \text { of } \\
\text { mothers of advantaged ages in the group of patients } 1 \text { year old and older. The overall figure } \\
\text { of } 13 \% \text { in false positives is significantly lower compared to about } 33 \% \text { in true Down } \\
\text { syndrome }(p=0.0003) \text {. }\end{array}$} \\
\hline \multirow{2}{*}{$\begin{array}{l}\text { Maternal } \\
\text { age }\end{array}$} & \multirow{2}{*}{$\begin{array}{l}\text { Down } \\
\text { syndrome }\end{array}$} & \multicolumn{4}{|c|}{ Patients with false positive diagnosis of Down syndrome } \\
\hline & & Neonates & Under 1 yo & $\begin{array}{l}1 \text { yo and } \\
\text { older }\end{array}$ & Total \\
\hline$<20$ & 87 & 6 & 3 & 1 & 10 \\
\hline $20-24$ & 378 & 6 & 7 & 5 & 18 \\
\hline $25-29$ & 367 & 15 & 3 & 5 & 23 \\
\hline $30-34$ & 324 & 10 & 4 & 2 & 16 \\
\hline $35-39$ & 352 & 2 & 2 & 3 & 7 \\
\hline $40+$ & 213 & $7.5 \%$ & $15 \%$ & $23.5 \%$ & $13 \%$ \\
\hline Total & 1721 & 40 & 20 & 17 & 77 \\
\hline
\end{tabular}

Table 4. Maternal ages in Down syndrome and in false positive diagnosis, 1970-2009 


\section{Discussion}

\subsection{Proportion of false positive cases}

Over the study period, 1129 postnatal cases of Down syndrome were identified. Regular trisomy 21 was observed in $90.9 \%$, translocation trisomy in $5.4 \%$, and mosaicism in $3.7 \%$ of the cases. These figures are in accordance with previous data worldwide. One hundredtwenty cases, referred for cytogenetic examination for suspicion of Down syndrome, displayed a normal karyotype, while eight children were diagnosed with another chromosome abnormality. Therefore, the proportion of misdiagnosed cases was $10.2 \%$ $(128 / 1129)$. Analysis of the literature (Table 5) showed these data to be in agreement with majority of previous studies. Data from Spain [Ballesta et al., 1997] is of particular interest regarding the object of the present publication. The authors performed rigorous clinical screening of patients with suspected Down syndrome followed by cytogenetic testing. Eleven of 71 (15.5\%) patients with psychomotor delay and features of Down syndrome were found to have a normal karyotype. On subsequent fluorescent in situ hybridization (FISH) testing, only one of them had triplication of the Down syndrome region on FISH testing.

When neonates were analyzed separately, the false positive rate has improved up to $7.2 \%$. Among publications where data on accuracy of Down syndrome diagnosis can be found there are some reporting on the prevalence of false positive diagnosis in neonates [Devlin \& Morrison, 2004; Fried, 1980; Hall, 1964; Hindley \& Medakkar, 2002; Melve et al., 2008; Sivakumar \& Larkins, 2004]. The rate of false positives in our sample appeared to be the lowest, being closer to figure of $9.6 \%$ in Norway [Melve et al., 2008]. Annual rate of false positive diagnosis varied significantly, from $0 \%$ in 1990, 1995, and in 2000 to $21 \%$ (9 of 42) in 2001 (Figure 1). Obviously this variation did not depend on the clinical experience of the referring doctors. Similar figures were reported by Melve et al. [2008], the highest annual number of false positives in neonates was 18 (18.9\%) and the lowest was 4 (4.8\%).

False positive diagnosis implies a great undue mental stress for parents, therefore maximizing clinical diagnostic accuracy is of importance [Hindley \& Medakkar, 2002]. Significance of expert clinical assessment of a patient before cytogenetic testing was explored by Sivakumar \& Larkins [2004]. They reported a more favorable accuracy rate from Birmingham Women's Hospital (25 of 29 suspected cases had trisomy 21) compared to the West Midland region (false positive rate $14 \%$ and $36 \%$, correspondingly). "This can be explained by the fact that the tertiary hospital may have more experienced neonatologists compared to the broad cohort of junior and senior pediatricians... We believe that an assessment by a senior pediatrician before testing may minimize the risk of negative results." [Sivakumar \& Larkins, 2004]. The data from the present study, that is a low false positive rate as the result of expert clinical assessment by clinical geneticists, support this suggestion.

\subsection{Degree of certainty about the diagnosis of Down syndrome 4.2.1 Degree of certainty about the diagnosis of Down syndrome in false positive cases}

Despite the widely held belief that the clinical diagnosis of Down syndrome is very obvious, some publications report on difficulties of clinical judgment arising in the neonatal period [Druce et al., 1995; Fried, 1980; Hall, 1966; Hindley \& Medakkar, 2002; Lee et al., 1961]. Factors which alter suspicion of Down syndrome are known to be early delivery and prematurity [Mikkelsen, 1988]. No data on sex difference in suspicion of Down syndrome or in degree of certainty of DS diagnosis were reported before. 


\begin{tabular}{|c|c|c|c|c|c|}
\hline Source & Country & $\begin{array}{l}\text { Study } \\
\text { period }\end{array}$ & Age of patients & $\begin{array}{l}\text { Number } \\
\text { of tested } \\
\text { patients }\end{array}$ & $\begin{array}{c}\text { Proportion of } \\
\text { false positive } \\
\text { diagnosis }\end{array}$ \\
\hline $\begin{array}{l}\text { Hamerton } \\
\text { et al, } 1965\end{array}$ & UK & $1960-1964$ & not specified & 173 & $16(9 \%)$ \\
\hline $\begin{array}{l}\text { Engel } \\
\text { et al., } 1970\end{array}$ & Germany & $1963-1968$ & various ages & 365 & $6(15 \%)$ \\
\hline \multirow{2}{*}{$\begin{array}{l}\text { Johnson } \\
\text { et al., } 1985\end{array}$} & Ohio, USA & 1970-1981 & various ages & 769 a & $48(6 \%)$ \\
\hline & $\begin{array}{c}\text { New York, } \\
\text { USA } \\
\end{array}$ & $1980-1983$ & various ages & $126^{b}$ & $10(8 \%)^{c}$ \\
\hline \multirow{2}{*}{$\begin{array}{l}\text { Szollar } \\
\text { et al., } 1983\end{array}$} & \multirow{2}{*}{ Hungary } & \multirow{2}{*}{$1970-1979$} & under 1 yo & 214 & $16(7.5 \%)$ \\
\hline & & & 1 yo and older & 85 & $3(3.5 \%)$ \\
\hline $\begin{array}{l}\text { Czeizel, } \\
1988 \\
\end{array}$ & Hungary & $1973-1982$ & various ages & 81 & $4(5 \%)$ \\
\hline $\begin{array}{l}\text { Baccichetti } \\
\text { et al., } 1990\end{array}$ & Italy & 1988 & $\begin{array}{l}\text { teenagers and } \\
\text { adults } \\
\text { predominantly }\end{array}$ & 116 & $14(12 \%)$ \\
\hline $\begin{array}{l}\text { Ballesta } \\
\text { et al., } 1997\end{array}$ & Spain & $\begin{array}{c}\text { not } \\
\text { specified }\end{array}$ & not neonates & 71 & $11(15.5 \%) \mathrm{d}$ \\
\hline $\begin{array}{l}\text { Ahmed } \\
\text { et al., } 2005\end{array}$ & Pakistan & 1998-2001 & various ages & 325 & $30(9 \%)$ e \\
\hline
\end{tabular}

$\mathrm{a}, \mathrm{b}$ cytogenetic confirmation in about $77 \%$ of the patients; c including one case with trisomy 18 ; $\mathrm{d}$ FISH study of 11 cases detected a partial trisomy 21 in one case; e including 12 cases with other chromosomal anomalies

Table 5. Accuracy of the clinical diagnosis of Down syndrome in patients of various ages

Data presented in Table 2 suggests that the level of certainty in false positives cases was comparably low, decreasing with the patients' age. The diagnosis at clinical examination seemed obvious in $22 \%$ of neonates and in only $6 \%$ of children 1 year and older. However a proportion of clinical diagnosis suggestive of mosaicism increased with the patients' age, from $3 \%$ in neonates to about $10 \%$ in the oldest group of patients. Surprisingly, despite a strong prevalence of females among false positive children, a higher level of certainty of Down syndrome diagnosis was given to male patients (Table 3). In males, unquestionable Down syndrome or suspected mosaicism were indications for cytogenetic testing in $20 \%$ and in $8.5 \%$ of the cases, while in females these figures were $14 \%$ and $4 \%$ respectively.

\subsubsection{Degree of certainty about the diagnosis of Down syndrome in confirmed cases}

The data reported above prompted the author to taking a quick look at degree of certainty of the clinical diagnosis in the cases of true Down syndrome. It was found that 17 of $106(16 \%)$ neonates with Down syndrome born during 2007-2009 had a questionable clinical diagnosis (including one diagnose accompanied with three question marks), among them there were 8 males and 9 females. Thus, at least in neonates with Down syndrome, there was no association of clinical suspicion of the diagnosis with the gender of the patient. 


\begin{tabular}{|l|l|c|c|c|}
\hline \multicolumn{1}{|c|}{ Source } & $\begin{array}{l}\text { Geographic } \\
\text { area }\end{array}$ & Study period & $\begin{array}{c}\text { Number of } \\
\text { tested patients }\end{array}$ & $\begin{array}{c}\text { Proportion of } \\
\text { false positive } \\
\text { diagnosis }\end{array}$ \\
\hline Hall, 1964 & Sweden & $1961-1962$ & 43 & $5(11.6 \%)$ \\
\hline Fried, 1980 & Israel & $1973-1977$ & 30 & $4(13.3 \%)$ \\
\hline $\begin{array}{l}\text { Hidley, \& Medakkar, } \\
2002\end{array}$ & UK & $1999-2000$ & 962 & $307(32 \%)^{\mathrm{a}}$ \\
\hline $\begin{array}{l}\text { Devlin \& Morrison, } \\
2004\end{array}$ & $\begin{array}{l}\text { Northern } \\
\text { Ireland }\end{array}$ & $1969-2001$ & $268 \mathrm{~d}$ & $82(31 \%) \mathrm{b}$ \\
\hline $\begin{array}{l}\text { Sivakumar \& Larkins, } \\
2004\end{array}$ & UK & $2000-2002$ & 233 & $85(36 \%)$ \\
\hline Melve et al., 2008 & Norway & $2001-2005$ & 376 & $36(9.6 \%)$ \\
\hline Present study & Russia & $1986-2009$ & 1146 & $83(7.2 \%)^{\mathrm{c}}$ \\
\hline
\end{tabular}

a including one case with 49,XXXXY; b including 5 females with another chromosomal abnormality; ${ }^{c}$ including 2 males and 6 females with another chromosomal abnormality; a neonates constitute $90 \%$ of the patients

Table 6. Accuracy of the clinical diagnosis of Down syndrome in neonates

\subsection{Sex ratio in Down syndrome}

\subsubsection{Sex ratio in cases considered or proved to be true Down syndrome}

Sex ratio in true Down syndrome is well known to be skewed towards males [Mikkelsen, 1988; Mutton et al., 1996]. Meta-analysis of publications reporting cytogenetic profile of Down syndrome worldwide [Kovaleva, 2002] showed typical male prevalence (SR 1.3) among both patients with regular trisomy 21 and carriers of translocation trisomy 21, either sporadic or inherited. The only exception is mosaic variant of trisomy, where some prevalence of females was documented (SR 0.96).

Several hypotheses have been put forward to explain the skewed sex ratio in Down syndrome. Meiotic disturbance (non-homologous co-orientation in male meiosis) [Kovaleva, 1992; Petersen et al. 1993], fertilization event (greater accessibility of Y-bearing sperm to ova disomic for chromosome 21 or promotion of non-disjunction in the ova by Y-bearing sperm) [Ferguson-Smith \& Yates, 1984; Kovaleva \& Mutton, 2005], and post-fertilization events (intrauterine selection against females) [Huether et al., 1996; Hook et al., 1999] have been discussed. Data from recent studies supports suggestion that male excess among live born with non mosaic trisomy 21 might be due to selection against female fetuses [Oliver et al., 2009; Kovaleva, 2010]. Female prevalence among carriers of mosaic trisomy was suggested to be a result of sex-specific chromosome loss in early embryogenesis [Kovaleva, 2005].

The trigger of the present study was an observation of an intriguing dynamics of sex ratio in Down syndrome in St. Petersburg (former Leningrad) within period of 1970-1996 [Kovaleva et al., 1999] subsequently confirmed by the meta analysis of the literature [Kovaleva, 2002]. It was a steady increase in sex ratio from a population figure of 1.05 or even less in the earliest studies in 1940's to 1.3 - 1.6 in the studies conducted during late 1980's (Figure 2). Analysis showed that this increase was accounted for by the growing use of karyotyping to 
confirm the diagnosis. Among individuals with a clinical diagnosis only, sex ratio was 0.97 (1160 males/1198 females) [Collman \& Stoller, 1962; Davidenkova et al., 1965; Huether, 1990; Kovaleva et al., 2001; Staples et al., 1991] while among individuals with confirmed trisomy 21 this figure was 1.31 (1918 males/1466 females) [Huether, 1990; Kovaleva et al., 2001; Mikkelsen et al., 1976; Mikkelsen et al., 1990; Sharav, 1991; Staples et al., 1991; Stoll et al., 1990; Wahrman \& Fried, 1970]. Correspondingly, in samples where proportion of clinical diagnosis only was 30\% and more, intermediate figure of 1.12 (1950 males/1742 females) [Baird \& Sadovnik, 1987; Christoderescu et al., 1977; Johnson et al., 1996; Kallen et al., 1996; Kovaleva et al., 2001; Staples et al., 1991] was observed. These observations raised a suggestion that low sex ratio in Down syndrome patients with clinical diagnosis only might be accounted by a large proportion of false positive diagnosis in females [Kovaleva, 2002].

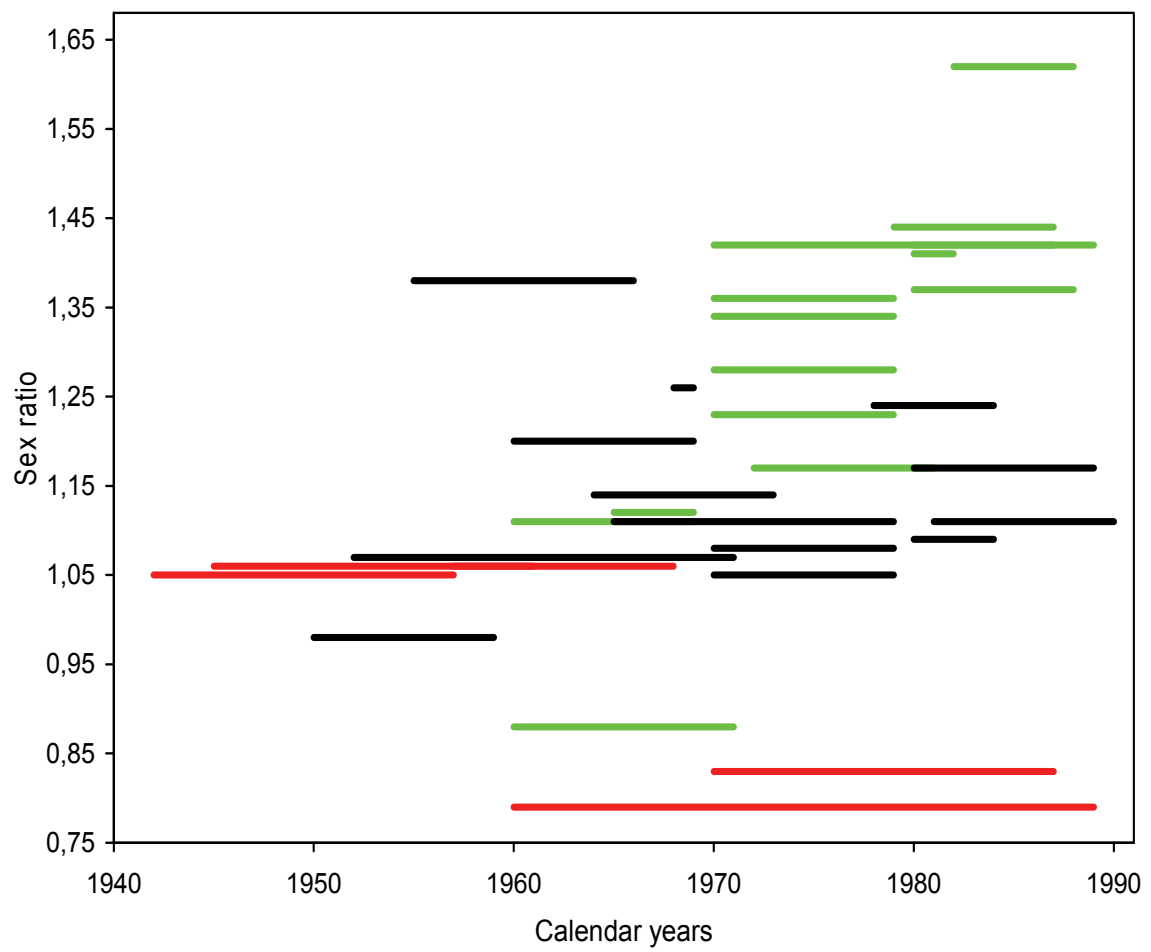

Fig. 2. Sex ratio in Down syndrome, data from epidemiological studies worldwide (adapted from Kovaleva [2002]). Red line: clinical diagnosis only; black line: clinical diagnosis or trisomy 21, green line: trisomy 21

\subsubsection{Sex ratio in false positive diagnosis}

Though theoretically, misdiagnosis should occur uniformly in both sexes, data from the present study demonstrates a significant female prevalence among false positive patients. In neonates, a five-fold prevalence of females over males was detected (17 males/ 86 females, $\mathrm{SR}=0.20$, different from population value of $1.06, \mathrm{p}<0.0001)$. Female excess diminished with older children; two-fold prevalence was found among children of the age up to 1 year 
old (24 males $/ 44$ females, $S R=0.55, \mathrm{p}=0.0052)$, and notable but statistically insignificant prevalence among patients aged 1 year and older ( 29 males $/ 35$ females, $S R=0.83, p>0.05$ ). Therefore, data from the present study supports the suggestion of low sex ratio in Down syndrome patients with clinical diagnosis only as the result of a large proportion of false positive diagnosis in females. However the reason of female predominance among the clinically suspected Down syndrome remains unclear.

Patients with clinical features of Down syndrome but without trisomy 21 were reported occasionally before the advent of molecular technologies allowing definite detection of Down syndrome critical region located at chromosome 21 [Hall, 1961; Hamerton \& Polani, 1962; Bowen et al., 1974]. As an explanation for absence of trisomy 21 in different tissues of patients with apparent manifestations of the syndrome, several suggestions were proposed: (1) low-level mosaicism, (2) the presence of the trisomic cell line in tissues other than those investigated, (3) elimination of the aberrant cell line in vivo or selective regress in vitro [Engel et al., 1970], and (4) gene mutation that might cause a "phenocopy" [Hall, 1962].

Subsequent studies showed the presence of a cryptic duplication of the Down syndrome critical region in individuals with clinical diagnosis of Down syndrome and an apparently normal karyotype [see for reference Forster-Gibson et al., 2001]. However several patients with mental retardation and Down syndrome phenotype, but without molecularly detectable duplication of the critical region, have been reported [McCormick et al., 1989; Ahlbom et al., 1996]. The majority of them were females. For example, a woman with clinically typical Down syndrome but apparently normal chromosomes, was extensively examined for the presence of any partial trisomy for any segment of chromosome 21 . Since the proposita's parents were half-sibs, and her sister suffered from the same disorder as the proposita, the authors suggested an autosomal recessive disorder which is phenotypically indistinguishable from Down syndrome [Ahlbom et al., 1996]. As it was mentioned above, FISH testing of 11 patients with developmental delay and clinically obvious Down syndrome revealed only one of them who had triplication of the critical Down syndrome region. Unfortunately the gender of the patients was not reported [Ballesta et al., 1997].

The data obtained in the present study suggest that gender in particularly significantly affects clinical suspicion of Down syndrome in neonates. Since characteristic features allowing suspicion of Down syndrome include facial dysmorphisms, one may hypothesize sex differences in the normal process of facial cranium ontogenesis during perinatal period.

In patients aged one year and older, sex ratio (0.83) appeared to be close to sex ratio typical to carriers of mosaic trisomy 21 (0.96). In this group, proportion of mothers of advanced age seemed to be increased which might support a suggestion of undetected mosaicism in some of these patients. An abnormal condition(s) specific to females might also be implicated in a proportion of the misdiagnosed cases.

\subsection{Implications of false positive-female-prevalence-phenomenon to Down syndrome epidemiology}

The observation of female prevalence in false positive clinically diagnosed cases allows an insight into the ground for reported sex ratio variability in Down syndrome. For example, the ECLAM (Estudio Colaborativo Latinoamericano de Malformaciones Congenitas) group reported as "an unusual finding" a markedly low sex ratio (0.98) found in 3,157 newborn Down syndrome patients in South America populations [Carothers et al., 2001]. Only 13\% of the patients were reported to have confirmed diagnosis, therefore, in the light of the data 
presented in this paper, a low sex ratio among patients mostly clinically diagnosed as Down syndrome, is a well expected finding.

Moreover, based on data on sex ratio in both all clinically diagnosed cases and true Down syndrome cases in a population where sufficient completeness of cytogenetic confirmation is not readily achievable, it is realizable to calculate a crude rate of false positives [Kovaleva, 2002]. For example, assuming all males among clinically diagnosed cases in ECLAM's sample to be true Down syndrome (which can not be absolutely correct since some false positive cases might be found among males) and typical for Down syndrome sex ratio to be 1.3, for 1563 males, 1203 females (not 1594) are expected, with odd number of 391 females. Resulted proportion of misdiagnosed cases is $391 / 3,157=12 \%$.

The results from the present study might have some further implications. (1) Overestimation of maternal age-specific rates due to false positive cases, in young women predominantly, might take place in the early years of monitoring of Down syndrome, as well as in populations with a high proportion of unconfirmed cases (those covered by Chernobyl fallout in the Former Soviet Republics). (2) It was generally accepted that maternal age specific risks were stable over time, and variations in population rates were explained by changing in maternal age composition [Huether et al., 1998; Carothers et al., 2001]. However if age-specific rates stay stable over long time, irrespective of increase in proportion of confirmed cases, it might indicate an increase in real rates. (3) The results from this study would suggest that the use of epidemiological data collected on Down syndrome prior to routine cytogenetic analysis, should be reconsidered in meta-analyses of Down syndrome population data.

\section{Conclusion}

The present study is the largest study to address the accuracy of clinical diagnosis of Down syndrome and the first one demonstrating that gender may affect a clinical suspicion of a chromosomal disease. The advantages of this study are well-defined geographical population, clinical screening of the cases suspected to have a chromosomal disease by experienced clinical geneticists prior to requesting for cytogenetic testing, a high completeness of cytogenetic confirmation of the Down syndrome diagnosis, and perfect recording of the cases on logbooks of the cytogenetic laboratory at the St. Petersburg Centre for Medical Genetics. Apparent limitations of this study are a lack of detailed clinical description of the cases and absence of follow-up. Additional studies, both clinical and genetic, would be reasonable for uncovering mechanism(s) responsible for the remarkable sex bias in clinical suspicion of Down syndrome.

\section{Acknowledgment}

The author's greatest thanks belong to Prof. Virginia C. Thurston (Indiana University School of Medicine) for helpful comments and amending the English in this paper.

\section{References}

Ahmed, I.; Ghafoor, T.; Samore, N.A. \& Chattha M.N. (2005). Down syndrome: clinical and cytogenetic analysis. Journal of the College of Physicians and Surgeons - Pakistan, Vol. 15, No.7 (July 2005), pp. 426-429, ISSN 1022-386X 
Baccichetti, C.; Lenzini, E. \& Pegoraro, R. (1990). Down syndrome in the Belluno district (Veneto Region, northeast Italy): age distribution and morbidity. American Journal of Medical Genetics. Supplement, No. 7, (n.d.), pp. 84-86, ISSN 1040-3787

Baird, P.A. \& Sadovnick, A.D. (1987). Life expectancy in Down syndrome. The Journal of Pediatrics, Vol. 110, No.6, (June 1987), pp. 849-854, ISSN 0022-3476

Ballesta, F.; Antich, J.; Aledo, R.; Milả, M.; Sanchez, A. \& Moreno, J. (1997). Down syndrome: genotype-phenotype correlation in 71 patients. Cytogenetics and Cell Genetics, Vol.77, Suppl. 1, (June 1997), p. 6, ISSN 0011-4537

Bowen, P.; Chernick, B.C.; Campbell, D.J. \& Rouget, A. (1974). Mild characteristic of Down syndrome with normal karyotype in cultured lymphocytes and skin fibroblasts. Birth Defects Original Articles Series, Vol.10, No.10, pp. 43-48, ISSN 0547-6844

Carothers, A.D.; Castilla, E.E.; Dutra, M.G. \& Hook, E.B. (2001). Search for ethnic, geographic, and other factors in the epidemiology of Down syndrome in South America: Analysis of data from the ECLAMC Project, 1967-1997. American Journal of Medical Genetics, Vol.103, No.2, (October 2001), pp. 149-156, ISSN 1040-3787

Christoderescu, D.; Berbescu, C.; Retereanu, A.; Constantinescu, E.; Ciupitu, A.; Urse M. \& Radu M. (1977). The incidence of Down's syndrome in Bucharest. A retrospective survey. Revue roumaine de medicine. Neurologie et psychiatrie. Vol.15, No.2, (AprilJune 1977), pp.147-154, ISSN 0377-502X

Collman, R.D. \& Stoller, A. (1962). A survey of mongoloid births in Victoria, Australia, 19421957. American Journal of Public Health and the Nation's Health, Vol.52, May 1962, pp. 813-829, ISSN 0002-9572

Czeizel, E. (1988). Some epidemiological characteristics of Down's syndrome in Hungary. Acta morphologica Hungarica, Vol.36, No.1-2, pp. 63-77, ISSN 0236-5391

Davidenkova, E.F.; Shtilbans, I.I. \& Verlinskaia, D.K. (1965). Some data on 181 newborn infants with Down's disease. Pediatriia, Vol.44, February 1965, pp. 67-72, ISSN 0031403X

Devlin, L. \& Morrison, P.J. (2004). Accuracy of the clinical diagnosis of Down syndrome. The Ulster Medical Journal, Vol. 73, No.1, (May 2004), pp. 4-12, ISSN 041-6193

Druce, M.; Cohen, I.J.; Naor, N. \& Shohat, M. (1995). Late diagnosis of Down syndrome due to incorrect cytogenetic diagnosis and extreme prematurity. Clinical Genetics, Vol.48, No. 4, (October 1995), pp. 192-194, ISSN $0009-9163$

Engel, W.; Reinwein, H.; Müller, I. \& Kunze, G. (1970). Chromosomenbefunde bei 365 patienten mit Down-syndrome oder Verdacht auf Down-syndrome. Humangenetik, Vol.8, No.4, (March 1970), pp. 307-311, ISSN 0018-7348

Ferguson-Smith, M.A. \& Yates, J.R.W. (1984). Maternal age-specific rates for chromosome aberrations and factors influencing them: report of a collaborative European study on 52965 amniocenteses. Prenatal Diagnosis, Vol.4, Special No, (Spring 1984), pp. 545, ISSN 0197-3851

Forster-Gibson, C.J.; Davies, J.; MacKenzie, J.J. \& Harrison, K. (2001). Cryptic duplication of $21 \mathrm{q}$ in an individual with a clinical diagnosis of Down syndrome. Clinical Genetics, Vol.59, No.6, (June 2001), pp. 438-443, ISSN 0009-9163

Hall, B. (1962). Down's syndrome (mongolism) with normal chromosomes. Lancet, Vol. 2, November 17, pp. 1026-1027, ISSN 0140-6736

Hall, B. (1964). Mongolism in newborns. A clinical and cytogenetic study. Acta Paediatrica Scandinavica. Supplementum, No.154, (n.d.), pp. 1-95

Hamerton, J.L. \& Polani, P.E. (1962). Down's syndrome (mongolism) with normal chromosomes. Lancet, Vol.2, December 8, p. 1229, ISSN 0140-6736 
Hamerton, J.L.; Gianelli, F. \& Polani, P.E. (1965). Cytogenetics of Down's syndrome (Mongolosm) I. Data on consecutive series of patients referred for genetic counseling and diagnosis. Cytogenetics, Vol.4, No.3, (n.d.), pp. 171-185, ISSN 0011-4537

Hindley, D. \& Medakkar, S. (2002). Diagnosis of Down's syndrome in neonates. Archives of Disease in Childhood. Fetal and Neonatal Edition, Vol.87, No. 3, (November 2002), pp. F220-F221, ISSN 1359-2998

Hook, E.B.; Cross, P.K. \& Mutton, D.E. (1999). Female predominance (low sex ratio) in 47,+21 mosaics. American Journal of Medical Genetics, Vol.84, No.4, (June 1999), pp. 316-319, ISSN 1040-3787

Huether, C.A. (1990). Epidemiological aspects of Down syndrome: sex ratio, incidence, and recent impact of prenatal diagnosis. Issues and Reviews in Teratology. Vol.5, (n.d.), pp. 283-316, ISSN 0740-8242

Huether, C.A.; Martin, R.L.M.; Stoppelman, S.M.; D'Souza, S.; Bishop, J.K.; Torfs, C.P.; Lorey, F.; May, K.M.; Hanna, J.S.; Baird, P.A. \& Kelley, J.C. (1996). Sex ratio in fetuses and live born infants with autosomal aneuploidy. American Journal of Medical Genetics, Vol.63, No.3, (June 1996), pp. 492-500, ISSN 1040-3787

Huether, C.A.; Ivanovich, J.; Goodwin, B.S.; Krivchenia, E.L.; Hertzberg, V.; Edmonds, L.D.; May, D.S. \& Priest, J.H. (1998). Maternal age specific risk rate estimates for Down syndrome among live births in whites and other races from Ohio and Metropolitan Atlanta, 1970-1989. Journal of Medical Genetics, Vol.35, No.6, (June 1998), pp. 482-490, ISSN 0022-2593

Johnson, K.M.; Huether, C.A.; Hook, E.B., Crowe, C.A.; Reeder, B.A.; Sommer, A.; McCorquodale, M.M. \& Cross, P.K. (1985). False positive reporting of Down syndrome on Ohio and New York birth certificates. Genetic Epidemiology, Vol.2, No.2, (n.d.), pp. 123-131, ISSN 0741-0395

Johnson, Z.; Lillis, D.; Delany, V.; Hayes, C. \& Dack, P. (1996) The epidemiology of Down syndrome in four counties in Ireland 1981-90. Journal of Public Health Medicine, Vol.18, No.1, (March 1996), pp.78-86, ISSN 0957-4832

Kallen, B.; Mastroiacovo, P. \& Robert, E. (1996). Major congenital malformations in Down syndrome American Journal of Medical Genetics, Vol.65, No.2, (October 1996), pp. 160 166, ISSN 1040-3787.

Kovaleva, N.V. (1992). Distributive pairing and aneuploidy in man. Genetika, Vol.28, No.10, (n.d.), pp. 5-15, ISSN 0016-1993

Kovaleva, N.V. (2002). Sex ratio in Down syndrome. A review. Tsitol Genet, Vol.36, No.6, (November-December 2002), pp. 54-69, ISSN 0563-3783

Kovaleva, N.V. (2005). Sex-specific instability in early human development. American Journal of Medical Genetics, Vol.136A, No.1, (April 2005), pp. 401-413, ISSN 1040-3787

Kovaleva, N.V. (2010, March 18). Germ-line transmission of trisomy 21: data from 80 families suggest an implication of grandmaternal age and a high frequency of female-specific rescue. Molecular Cytogenetics, BioMed Central, Retrieved from http://www.molecularcytogenetics.org/content/3/1/7

Kovaleva, N.V.; Butomo, I.V.; Verlinskaya, D.K.; Ilyashenko, N.Y.; Pantova, I.G.; Prozorova, M.V.; Khitrikova, L.E. \& Shandlorenko, S.K. (1999). Karyological characterization of Down syndrome: clinical and theoretical aspects. Tsitologiia, Vol.41, No.12, (n.d.), pp. 1015-1021, ISSN 0041-3771

Kovaleva, N.V.; Butomo, I.V. \& Körblein, A. (2001). Sex ratio in Down syndrome. Studies on patients with confirmed trisomy 21. Tsitologiia $i$ Genetica, Vol.36, No.6, (NovemberDecember 2001), pp. 43-49, ISSN 0564-3783 
Kovaleva, N.V. \& Mutton, D.E. (2005). Epidemiology of double aneuploidies involving chromosome 21 and sex chromosomes. American Journal of Medical Jenetics, Vol.134A, No.4, (August 2005), pp. 24-32, ISSN 1040-3787

Lee, C.H.; Schmid, W. \& Smith, P.M. (1961). Definitive diagnosis of mongolism in newborn infants by chromosome studies. JAMA, Vol.178, December 9, (December 1961), pp. 1030-1032, ISSN 0098-7484

Melve, K.K.; Lie, R.T.; Skjaerven, R.; Van Der Hagen, C.B.; Gradek, G.A.; Jonsrud, C.; Braathen, G.J. \& Irgens, L.M. (2008). Registration of Down syndrome in the Medical Birth Registry of Norway: validity and time trends. Acta Obstetrica et Gynecologica Scandinavica, Vol.87, No.8, (n.d.), pp. 824-830, ISSN 0001-6349

McCormick, M.K.; Schinzel, A.; Petersen, M.B.; Stetten, G.; Driscoll, D.J.; Cantu, E.S.; Tranebjaerg, L.; Mikkelsen, M.; Watkins, P.C. \& Antonarakis, S.E. (1989). Molecular genetic approach to the characterization of the "Down syndrome region" of chromosome 21. Genomics, Vol.5, No. 2, (August 1989), pp. 325-331, ISSN 0888-7543

Mikkelsen, M.; Fischer, G.; Stene, J.; Stene, E. \& Petersen, E. (1976). Incidence study of Down's syndrome in Copenhagen, 1960-1971: with chromosome investigation. Annals of Human Genetics, Vol.40, No.2, (November 1976), pp.177-182, ISSN 0003-4800

Mikkelsen, M. (1988). The incidence of Down's syndrome and progress towards its reduction. Philosophical Transactions of the Royal Society. Biological Sciences, Vol.319, No.1194, (June 1988), pp. 315-324, ISSN 0962-8436

Mikkelsen, M.; Poulsen, H. \& Nielsen, K.G. (1990). Incidence, survival, and mortality in Down syndrome in Denmark. American Journal of Medical Genetics. Supplement, No. 7, (n.d.), pp. 75-78, ISSN 1040-3787

Mutton, D.; Alberman, E. \& Hook, E.B. (1996). Cytogenetic and epidemiological findings in Down syndrome, England and Wales 1989 to 1993. Journal of Medical Genetics, Vol.33, No.3, (May 1996), pp. 387-394, ISSN 0022-2593

Oliver, T.R.; Bhise, A.; Feingold, E.; Tinker, S.; Masse, N. \& Sherman, S.L. (2009). Investigation of factors associated with paternal non disjunction of chromosome 21. American Journal of Medical Genetics, Vol.149A, No.8, (August 2009), pp. 1685-1690, ISSN 1040-3787

Petersen, M.B.; Antonarakis, S.E.; Hassold, T.J.; Freeman, S.B.; Sherman, S.L.; Avramopoulos, D. \& Mikkelsen, M. (1993). Paternal non disjunction in trisomy 21: excess of male patients. Human Molecular Genetics, Vol.2, No.10, (October 1993), pp. 1691-1695, ISSN 0964-6906

Sharav, T. (1991). Aging gametes in relation to incidence, gender, and twinning in Down syndrome. American Journal of Medical Genetics, Vol.39, No.1, (April 1991), pp.116118, ISSN 1040-3787

Sivakumar, S. \& Larkins, S. (2004). Accuracy of clinical diagnosis in Down's syndrome. Archives of Diseases in Childhood. Vol.89, No.7, (July 2004), p. 691, ISSN 0003-9888

Staples, A.J.; Sutherland, G.R.; Haan, E.A. \& Clisby, S. (1991). Epidemiology of Down syndrome in South Australia (1960-89). American Journal of Human Genetics, Vol.49, No.5, (November 1991), pp.1014-1024, ISSN 0002-9297

Stoll, C.; Alembik, Y.; Dott, B. \& Roth, M.P. (1990). Epidemiology of Down syndrome in 118, 265 consecutive births. American Journal of Medical Genetics. Supplement, No. 7, (n.d.), pp. 79-83, ISSN 1040-3787

Szollar, J.; Osztovics, M.; Pazonyi, I. \& Balogh, L. (1983). The frequency of Down syndrome in a Budapest study during 1970-1979. Clinical Genetics, Vol. 23, No.3, p. A249, ISSN 0009-9163

Wahrman, J. \& Fried, K. (1970) The Jerusalem prospective newborn survey of mongolism. Annals of New York Academy of Sciences, Vol.171, No.2, (October 1970), pp. 341-360, ISSN 0077-8923 


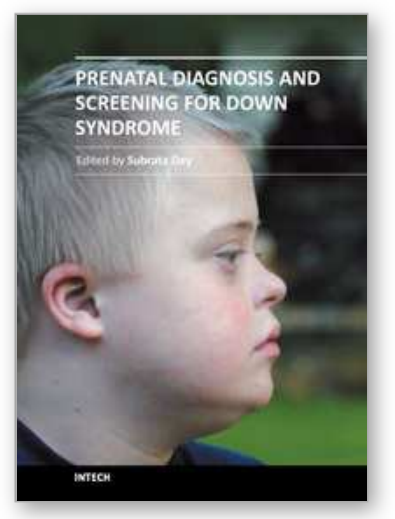

\author{
Prenatal Diagnosis and Screening for Down Syndrome \\ Edited by Prof. Subrata Dey
}

ISBN 978-953-307-355-2

Hard cover, 232 pages

Publisher InTech

Published online 17, August, 2011

Published in print edition August, 2011

This book provides a concise yet comprehensive source of current information on Down syndrome. Research workers, scientists, medical graduates and paediatricians will find it an excellent source for reference and review. This book focuses on exciting areas of research on prenatal diagnosis - Down syndrome screening after assisted reproduction techniques, noninvasive techniques, genetic counselling and ethical issues. Whilst aimed primarily at research worker on Down syndrome, we hope that the appeal of this book will extend beyond the narrow confines of academic interest and be of interest to a wider audience, especially parents and relatives of Down syndrome patients.

\title{
How to reference
}

In order to correctly reference this scholarly work, feel free to copy and paste the following:

Natalia V. Kovaleva (2011). Gender Affects Clinical Suspicion of Down Syndrome, Prenatal Diagnosis and Screening for Down Syndrome, Prof. Subrata Dey (Ed.), ISBN: 978-953-307-355-2, InTech, Available from: http://www.intechopen.com/books/prenatal-diagnosis-and-screening-for-down-syndrome/gender-affectsclinical-suspicion-of-down-syndrome

\section{INTECH}

open science | open minds

\section{InTech Europe}

University Campus STeP Ri

Slavka Krautzeka 83/A

51000 Rijeka, Croatia

Phone: +385 (51) 770447

Fax: +385 (51) 686166

www.intechopen.com

\section{InTech China}

Unit 405, Office Block, Hotel Equatorial Shanghai

No.65, Yan An Road (West), Shanghai, 200040, China

中国上海市延安西路65号上海国际贵都大饭店办公楼 405 单元

Phone: +86-21-62489820

Fax: +86-21-62489821 
(C) 2011 The Author(s). Licensee IntechOpen. This chapter is distributed under the terms of the Creative Commons Attribution-NonCommercialShareAlike-3.0 License, which permits use, distribution and reproduction for non-commercial purposes, provided the original is properly cited and derivative works building on this content are distributed under the same license. 